\section{Monitoring emisija onečišćujućih tvari na području grada Tuzle}

\author{
E. Hodžić, ${ }^{*}$ E. Alićb i E. Horozića \\ a Tehnološki fakultet, Univerzitet u Tuzli, Urfeta Vejzagića 8, 75000 Tuzla, BiH \\ b Medicinski fakultet, Univerzitet u Tuzli, 1, Univerzitetska 1, 75000 Tuzla, BiH
}

https://doi.org/10.15255/KUl.2020.024

KUI-52/2020

Izlaganje sa znanstvenog skupa

Prispjelo 21. travnja 2020.

Prihvaćeno 17. kolovoza 2020.

Ovo djelo je dano na korištenje pod Creative Commons Attribution 4.0 International License

\begin{abstract}
Sažetak i lebdeće čestice $\mathrm{PM}_{2,5}$, na tri lokacije u Tuzli. $153,2 \mu \mathrm{g} \mathrm{m}^{-3}$.

\author{
Ključne riječi
}

Onečišćenje zraka, okoliš, onečišćujuće tvari, monitoring, zdravlje
\end{abstract}

Onečišćenje zraka se sve više smatra značajnim rizikom po zdravlje stanovništva. Uslijed rada industrije, velike koncentracije prometa i individualnih ložišta, na području grada Tuzle već je dulje vrijeme prisutan problem onečišćenja zraka. Tvari koje onečišćuju okoliš predstavljaju rizik za zdravlje ljudi i drugih živih bića, a onečišćenje zbog sagorijevanja fosilnih goriva je na vodećem mjestu crne ljestvice prijetnji za zdravlje. Onečišćenost okoliša može uzrokovati niz bolesti, poput astme, alergija, raznih oblika raka, bolesti srca i krvožilnog sustava, problema s plodnošću, neuroloških problema i slično.

U ovom radu prikazani su rezultati monitoringa emisije polutanata u razdoblju od 1. 1. 2019. do 31. 12. 2019. godine. Proveden je monitoring zraka za polutante: sumporov dioksid $\left(\mathrm{SO}_{2}\right)$, dušikov dioksid $\left(\mathrm{NO}_{2}\right)$, ugljikov monoksid $(\mathrm{CO})$, ozon $\left(\mathrm{O}_{3}\right)$

Rezultati ukazuju na to da je tijekom sezone grijanja, odnosno zimskih mjeseci kvaliteta zraka u urbanom području grada Tuzle vrlo loša. Najveća koncentracija sumporova dioksida zabilježena je u prosincu na mjernoj stanici Bukinje i iznosila je 271,7 $\mathrm{g} \mathrm{m} \mathrm{m}^{-3}$, također u istom mjesecu, na mjernoj stanici Skver zabilježena je koncentracija lebdećih čestica $\mathrm{PM}_{2,5}$ od

\section{Uvod}

Onečišćenje je prisutnost neke strane kemijske tvari u okolišu u koncentraciji ili nepostojanom obliku koji u kraćem vremenu ne uzrokuje izravnu štetu za zdravlje ljudi ili drugih živih organizama.

Onečišćenje zraka se sve više smatra značajnim rizikom po zdravlje stanovništva. ${ }^{1}$ Tvari koje onečišćuju okoliš nanose veliku štetu živim bićima, a onečišćenje zbog sagorijevanja fosilnih goriva na vodećem je mjestu crne ljestvice prijetnji za zdravlje. Istraživanja provedena u posljednjih deset godina pokazala su da se velik dio oboljenja i smrtnih slučajeva može povezati upravo s onečišćenjem zraka. ${ }^{2,3}$

Onečišćujuće tvari su tvari (kemijski elementi i spojevi) ili skupine tvari koje su toksične, postojane i sklone bioakumulaciji te druge tvari ili skupine tvari koje uzrokuju jednaku razinu zabrinutosti. Onečišćujuće tvari iz zraka ulaze u organizam kroz dišni sustav, kožu i probavni sustav. Mnoge organske tekućine, plinovite pa i čvrste tvari mogu proći kroz neoštećenu kožu. Čvrste tvari raspršene kao prašina i dimovi mogu se apsorbirati kroz pluća, ali se mogu i prenijeti s ruku na hranu te na taj način dospjeti u probavni sustav. Najizloženija je i najosjetljivija sluznica dišnog sustava s alveolarnom površinom pluća, koju čini
$15 \mathrm{~m}^{2}$ opne između krvi i zraka. Ljudski organizam različito reagira na štetne tvari. Neke tvari izazivaju akutni učinak već pri prvoj izloženosti, druge pokazuju toksični učinak nakon nekoliko dana ili tjedana ili nakon dugotrajnog i ponavljanog izlaganja. Uz akutnu ili kroničnu bolest, štetne tvari iz atmosfere mogu izazvati i ometanje rasta i razvoja ili skraćenje života, smetnje važnih fizioloških funkcija (ventilacije pluća, prijenosa kisika, rada osjetila, pokretljivosti) te osjećaj neugode i nakupljanje onečišćenja u organizmu, pa čak i smrt. $4,5,6,7,8,9,10$

Onečišćenje zraka ne oštećuje jednako sva tkiva, odnosno sve stanice ljudskog organizma. Učinak ovisi o koncentraciji i trajanju djelovanja onečišćenja, njegovim fizikalno-kemijskim svojstvima, mjestu djelovanja i zdravstvenom stanju organizma. ${ }^{11}$

Za prikupljanje podataka o kvaliteti zraka, provođenje monitoringa, ali i radi informiranosti građana, postavljaju se mjerne stanice koje mjere kvalitetu zraka u urbanim područjima. Nadzor kvalitete zraka i emisije polutanata od 2003. godine u Tuzli sustavno se provodi na postavljenim mjernim stanicama i predstavlja osnovu procjene rizika zdravstvenih poremećaja. Tako je u Tuzli, kao najvećem privrednom centru Tuzlanskog kantona, gdje je onečišćenje zraka dugogodišnji problem, postavljeno pet mjernih stanica

\footnotetext{
*Autor za dopisivanje: Emir Hodžić

e-pošta: hemir49@yahoo.com
} 
i to na mjestima: Skver, BKC (Bosanski kulturni centar), Bukinje, Lukavac i Živinice, koje provode monitoring zraka onečišćujućih tvari: $\mathrm{SO}_{2}, \mathrm{NO}_{2}, \mathrm{CO}, \mathrm{O}_{3}$ i $\mathrm{PM}_{2,5}{ }^{12}$

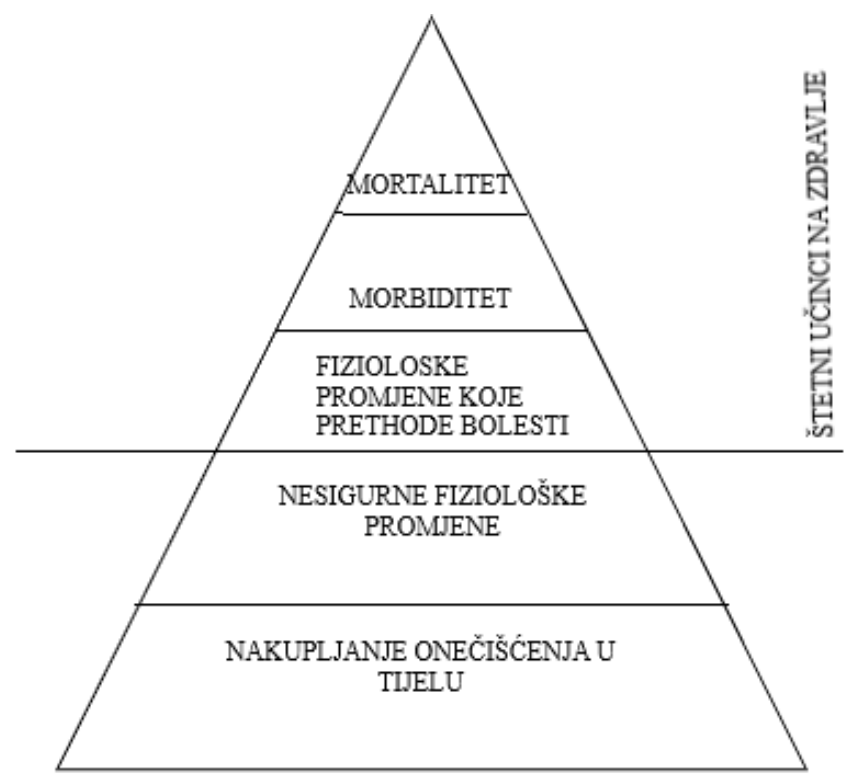

Slika 1 - Biološki odgovori ljudskog organizma na izloženost onečišćenju

Fig. 1 - Biological responses of the human organism to pollution exposure

\subsection{Onečišćujuće tvari u zraku}

Postoji mnogo spojeva koji mogu onečistiti zrak. Među najčešćim onečišćujućim tvarima u zraku koje utječu na zdravlje ljudi su lebdeće čestice (PM), ozon $\left(\mathrm{O}_{3}\right)$, dušikovi oksidi $\left(\mathrm{NO}_{x}\right)$, sumporov dioksid $\left(\mathrm{SO}_{2}\right)$ i ugljikov monoksid (CO). Mnoge onečišćujuće tvari često su međusobno povezane i teško je razdvojiti njihov utjecaj. Također, postoje značajna međudjelovanja između onečišćujućih tvari, što otežava određivanje utjecaja koji nastaju djelovanjem svake onečišćujuće tvari pojedinačno. ${ }^{13}$ Većina sustava za monitoring onečišćenja zraka mjere dva tipa lebdećih čestica (PM):

- $\quad \mathbf{P M}_{\mathbf{1 0}}$ - lebdeće čestice promjera manjeg od 10 mikrona u promjeru

- $\quad \mathbf{P M}_{2,5}$ - lebdeće čestice promjera manjeg od 2,5 mikrona u promjeru

$\mathbf{P M}_{10}$ se obično sastoji od sulfata, nitrata, amonijaka, natrijeva klorida, crnog ugljena i teških metala. $\mathrm{PM}_{10}$ je štetan za zdravlje jer može izazvati blokadu i zapaljenje nazalnih i bronhijalnih prolaza, izazivajući niz dišnih poremećaja koji mogu voditi ka bolesti ili čak i smrti. PM $_{10}$ je česta komponenta onečišćenja zraka u zatvorenim prostorima i šumskih požara. ${ }^{14}$
$\mathbf{P M}_{2,5}$ je obično produkt loženja fosilnih goriva, dolazi iz auspuha motornih vozila, termoelektrana i industrijske proizvodnje. $^{15}$

Ozon $\left(\mathbf{O}_{3}\right)$ se formira kemijskom reakcijom u kojoj sudjeluju sunčevo svjetlo, dušikovi oksidi i hlapljivi organski spojevi, što kao rezultat ima da najviše vrijednosti prizemnog ozona budu izmjerene za vrijeme toplih, sunčanih dana i to obično poslije podneva. ${ }^{16}$

Dušikov dioksid $\left(\mathrm{NO}_{2}\right)$ jedan je od najvažnijih onečišćujućih tvari zraka koji je proizvod sagorijevanja fosilnih goriva. Češće je prisutan u blizini puteva i tvornica ili u zatvorenim prostorima gdje se plin upotrebljava za kuhanje. $^{17}$

Sumporov dioksid $\left(\mathbf{S O}_{2}\right)$ je bezbojan plin vrlo oštrog mirisa. Nastaje spaljivanjem fosilnih goriva, ugljena i nafte koja su bogata sumporom ili prilikom topljenja mineralne rude koja sadrži sumpor. Sumporov dioksid u reakciji s vodom uzrokuje stvaranje kiselih kiša koje štetno utječu na okoliš. ${ }^{18}$

Ugljikov monoksid (CO) je bezbojan plin, bez mirisa, koji uglavnom nastaje kao jedan od produkata ispušnog sustava motornih vozila. Ostali izvori su postrojenja za spaljivanje i sagorijevanje goriva. ${ }^{19}$

U Zakonu o zaštiti zraka ${ }^{20}$ definirane su granične vrijednosti, tolerantne vrijednosti i vrijednosti pragova upozorenja i uzbune za onečišćujuće tvari koje se obrađuju u ovom radu. Granična vrijednost predstavlja maksimalnu dopuštenu koncentraciju onečišćujuće tvari u zraku. Vrijednosti za pojedine onečišćujuće tvari određene su znanstvenim istraživanjima s ciljem izbjegavanja, sprječavanja ili smanjivanja njihovih štetnih utjecaja na ljudsko zdravlje i okoliš u cjelini. Granica tolerancije predstavlja postotak dopuštenog prekoračenja granične vrijednosti pod propisanim uvjetima. Tolerantna vrijednost je granična vrijednost uvećana za granicu tolerancije. Prag upozorenja predstavlja razinu iznad koje postoji rizik za ljudsko zdravlje uslijed kratkog izlaganja za iznimno osjetljive dijelove stanovništva i o kome je potrebno dati najnovije informacije. Prag uzbune je razina iznad koje postoji rizik za ljudsko zdravlje prilikom kratkog izlaganja i na kojem će biti poduzeti izravni koraci. ${ }^{20}$

Epizoda je vremenski ograničeno razdoblje trajanja povišenih koncentracija onečišćujućih tvari u zraku ("epizoda" je usvojeni međunarodni termin za označavanje posebnih situacija) i traje 3 - 5 dana. Epizode povećanih koncentracija onečišćujućih tvari u zraku su pripravnost, upozorenje i uzbuna. Epizode se proglašavaju na osnovi izmjerenih ili proračunatih prosječnih vrijednosti koncentracija onečišćujućih tvari u zraku. 
Tablica 1 - Granične, tolerantne i vrijednosti praga upozorenja i uzbune za onečišćujuće tvari propisane Pravilnikom o načinu provođenja monitoringa kvalitete zraka i definiranju vrsta onečišćujućih tvari, graničnih vrijednosti i drugih standarda kvalitete zraka ("Službene novine FBiH", broj: 1/12)

Table 1 - Limit, tolerant and warning and alert threshold values for pollutants prescribed by the Rulebook on the manner of monitoring air quality and defining the types of pollutants, limit values and other air quality standards ("Official Gazette of FB\&H", No. 1/12)

\begin{tabular}{|c|c|c|c|c|c|c|c|c|c|c|}
\hline & \multicolumn{4}{|c|}{ Granična vrijednost } & \multicolumn{4}{|c|}{ Tolerantna vrijednost } & \multirow{2}{*}{$\begin{array}{c}\begin{array}{c}\text { Prag } \\
\text { upozorenja }\end{array} \\
1 \mathrm{~h}\end{array}$} & \multirow{2}{*}{$\begin{array}{c}\begin{array}{c}\text { Prag } \\
\text { uzbune }\end{array} \\
1 \mathrm{~h}\end{array}$} \\
\hline & $1 \mathrm{~h}$ & $8 \mathrm{~h}$ & $24 \mathrm{~h}$ & god. & $1 \mathrm{~h}$ & $8 \mathrm{~h}$ & $24 \mathrm{~h}$ & god. & & \\
\hline $\begin{array}{l}\mathrm{SO}_{2} \\
\text { (sumporov } \\
\text { dioksid) } \\
/ \mu \mathrm{g} \mathrm{m}^{-3}\end{array}$ & 350 & - & 125 & 50 & $\begin{array}{l}485-2012 \\
470-2013 \\
455-2014 \\
440-2015 \\
425-2016 \\
410-2017 \\
395-2018 \\
380-2019 \\
365-2020 \\
350-2021\end{array}$ & - & 125 & 50 & $\begin{array}{l}485-2012 \\
470-2013 \\
455-2014 \\
440-2015 \\
425-2016 \\
410-2017 \\
395-2018 \\
380-2019 \\
365-2020 \\
350-2021\end{array}$ & 500 \\
\hline $\begin{array}{l}\mathrm{NO}_{2} \\
\text { (dušikov } \\
\text { dioksid) } \\
/ \mu \mathrm{gm}^{-3}\end{array}$ & 200 & - & 85 & 40 & $\begin{array}{l}290-2012 \\
280-2013 \\
270-2014 \\
260-2015 \\
250-2016 \\
240-2017 \\
230-2018 \\
220-2019 \\
210-2020 \\
200-2021\end{array}$ & - & $\begin{array}{c}121-2012 \\
117-2013 \\
113-2014 \\
109-2015 \\
105-2016 \\
101-2017 \\
97-2018 \\
93-2019 \\
89-2020 \\
85-2021\end{array}$ & $\begin{array}{l}58-2012 \\
56-2013 \\
54-2014 \\
52-2015 \\
50-2016 \\
48-2017 \\
46-2018 \\
44-2019 \\
42-2020 \\
40-2021\end{array}$ & $\begin{array}{l}290-2012 \\
280-2013 \\
270-2014 \\
260-2015 \\
250-2016 \\
240-2017 \\
230-2018 \\
220-2019 \\
210-2020 \\
200-2021\end{array}$ & 400 \\
\hline $\begin{array}{l}\mathrm{CO} \\
\text { (ugljikov } \\
\text { monoksid) } \\
/ \mathrm{mg} \mathrm{m}^{-3}\end{array}$ & - & 10 & 5 & 3 & & $\begin{array}{l}14,8-2012 \\
13,6-2013 \\
12,4-2014 \\
11,2-2015 \\
10,0-2016\end{array}$ & $\begin{array}{l}-2012 \\
8-2013 \\
7-2014 \\
6-2015 \\
5-2016 \\
\end{array}$ & 3 & - & - \\
\hline $\begin{array}{l}\mathrm{O}_{3} \\
\text { (prizemni } \\
\text { ozon) } \\
/ \mu \mathrm{g} \mathrm{m}^{-3}\end{array}$ & - & 120 & - & - & - & - & - & - & 180 & 240 \\
\hline $\begin{array}{l}\mathrm{PM}_{2,5} \\
\text { (lebdeće } \\
\text { čestice) } \\
/ \mu \mathrm{gg} \mathrm{m}^{-3}\end{array}$ & - & - & - & 25 & - & - & - & $\begin{array}{l}29,5-2012 \\
29,0-2013 \\
28,5-2014 \\
28,0-2015 \\
27,5-2016 \\
27,0-2017 \\
26,5-2018 \\
26,0-2019 \\
25,5-2020 \\
25,0-2021\end{array}$ & - & - \\
\hline
\end{tabular}


Tablica 2 - Utvrđene vrijednosti kvalitete zraka za epizodne situacije (vrijednosti koje nedostaju u tablici nisu propisane Federalnim Pravilnikom)

Table 2 - Determined air quality values for episodic situations (missing values in the table are not prescribed by the Federal Regulations)

\begin{tabular}{l|c|c|c}
\hline \multirow{2}{*}{ Onečišćujuća tvar } & \multicolumn{2}{|c}{ Utvrđene satne vrijednosti $/ \mu \mathrm{m}^{-3}$} \\
\cline { 2 - 4 } & za epizodu pripravnosti & za epizodu upozorenja & za epizodu uzbune \\
\hline sumporov dioksid $\left(\mathrm{SO}_{2}\right)$ & 350 & 380 & 500 \\
\hline dušikov dioksid $\left(\mathrm{NO}_{2}\right)$ & 200 & 220 & 400 \\
\hline ozon $\left(\mathrm{O}_{3}\right)$ & - & 180 & 240 \\
\hline
\end{tabular}

\section{Eksperimentalni dio}

Na osnovi članka 21. Pravilnika o načinu provođenja monitoringa kvalitete zraka i definiranju vrsta onečišćujućih tvari, graničnih vrijednosti i drugih standarda kvalitete $z^{2}$ kaka $^{21}$ nadležno kantonalno Ministarstvo prati i informira javnost o kvaliteti zraka na području Tuzlanskog kantona. ${ }^{21}$ Održavanje Sistema za praćenje kvalitete zraka, kao i informiranje javnosti o kvaliteti zraka, koje se provodi svakodnevno putem medija i službene mrežne stranice Vlade Tuzlanskog kantona, ${ }^{22}$ u nadležnosti je Ministarstva prostornog uređenja i zaštite okolice Tuzlanskog kantona. ${ }^{23}$

Mjerne stanice smještene su na lokacijama Skver (MS1), Bosanski kulturni centar (MS2), Bukinje (MS3), Lukavac (MS4) i Živinice (MS5). Mjerne stanice provode monitoring zraka specijaliziranim uređajima koji mjere sljedeće onečišćujuće tvari: $\mathrm{SO}_{2}, \mathrm{NO}_{2}, \mathrm{CO}, \mathrm{O}_{3}$ i lebdeće čestice $\mathrm{PM}_{2,5}$. Ti uređaji vrše satno mjerenje onečišćujućih tvari i podatci koji se dobiju s tih mjernih stanica sakupljaju se i na osnovu njih se izrađuju dnevni, mjesečni i godišnji izvještaji. Mjerne stanice su strateški raspoređene $u$ urbanoj zoni grada: MS1 se nalazi uz magistralni put u neposrednoj blizini centra, MS2 se nalazi u blizini željezničkog kolodvora i glavne autobusne stanice i MS3 je u neposrednoj blizini termoelektrane. Na osnovi podataka o lokacijama mjernih stanica može se zaključiti uzrok onečišćenja zraka u tim dijelovima grada.

$U$ ovom radu obrađeni su podatci $s$ tri mjerne stanice: Skver, Bosanski kulturni centar i Bukinje, u razdoblju od 1. 1. 2019. do 31. 12. 2019. godine, a podatci su preuzeti sa službene mrežne stranice Vlade Tuzlanskog kantona.

\section{Rezultati i rasprava}

Rezultati monitoringa potvrđuju prisutnost već navedenih štetnih tvari i potvrđuju prekoračenja njihovih koncentracija, naročito u zimskim mjesecima. ${ }^{24}$

Na slici 2 prikazana je prosječna mjesečna koncentracija $\mathrm{SO}_{2}$. Dobiveni rezultati pokazuju česta prekoračenja mjesečnih koncentracija $\mathrm{SO}_{2}$ u zimskom razdoblju, a mjesec s najvećim onečišćenjem je prosinac.
Putem mjernih stanica za praćenje kvalitete zraka utvrđeno je prekoračenje maksimalne dopuštene koncentracije $\mathrm{SO}_{2}$ na godišnjoj razini u siječnju, veljači i prosincu na sve tri mjerne stanice, u ožujku na dvije mjerne stanice (Skver i BKC) i u travnju na jednoj mjernoj stanici (Skver).

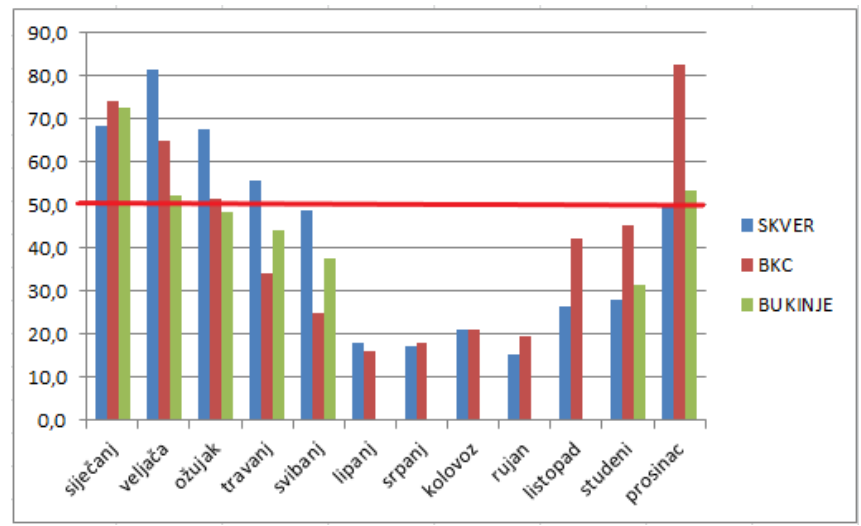

Slika 2 - Prosječne mjesečne vrijednosti za $\mathrm{SO}_{2}$

Fig. 2 - Average monthly values for $\mathrm{SO}_{2}$

Prema izvještaju o kvaliteti zraka na području Tuzlanskog kantona, putem mjernih stanica za praćenje kvalitete zraka utvrđen je broj vrijednosti satnih intervala za cijelu godinu, kada su koncentracije $\mathrm{SO}_{2}$ prelazile vrijednosti epizoda pripravnosti, upozorenja i uzbune, i to: 46 puta vrijednosti epizode pripravnosti, 35 puta prag upozorenja i 23 puta prag uzbune. Sumporov dioksid može utjecati na respiratorni sustav, izazivajući kašalj, stvaranje sekreta, pojačavanje astme i kroničnog bronhitisa. Studije su pokazale da se izlaganjem povećanim koncentracijama sumporova dioksida povećava smrtnost, posebno u dijelu populacije s bolestima srca i pluća. ${ }^{25}$

Na slici 3 je prikazana prosječna mjesečna koncentracija $\mathrm{NO}_{2}$. Rezultati monitoringa pokazuju prisutnost određenih koncentracija $\mathrm{NO}_{2}$ i prema rezultatima se utvrđuje da je mjesec s najvećim onečišćenjem u kalendarskoj godini siječanj.

Putem mjernih stanica za praćenje kvalitete zraka utvrđeno je da je došlo do prekoračenja maksimalne dopuštene koncentracije $\mathrm{NO}_{2}$ na godišnjoj razini i to u siječnju na jednoj mjernoj stanici (BKC). Putem mjernih stanica za praćenje kvalitete zraka na području Tuzlanskog kantona 
utvrđen je broj vrijednosti satnih intervala za cijelu godinu, kada su koncentracije $\mathrm{NO}_{2}$ prelazile vrijednosti epizoda pripravnosti, upozorenja i uzbune, i to: jedan put vrijednosti epizode pripravnosti, jedan put prag upozorenja i jedan put prag uzbune. Dušikovi oksidi imaju značajnu ulogu pri pojačavanju postojeće bolesti pluća, astme, bronhijalnih simptoma, upale pluća i smanjenju ukupne funkcije pluća. ${ }^{26}$

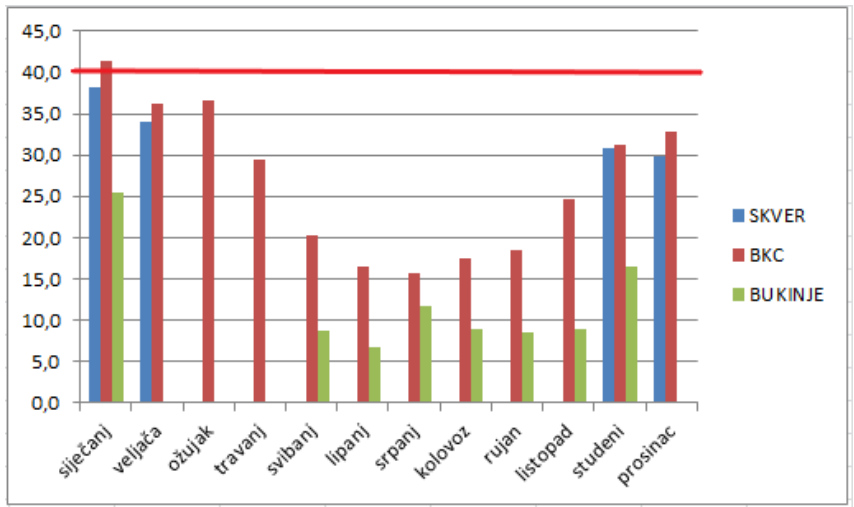

Slika 3 - Prosječne mjesečne vrijednosti za $\mathrm{NO}_{2}$

Fig. 3 - Average monthly values for $\mathrm{NO}_{2}$

Na slici 4 prikazana je prosječna mjesečna koncentracija CO. Putem mjernih stanica za praćenje kvalitete zraka utvrđeno je da nije došlo do prekoračenja maksimalne dopuštene koncentracije CO na godišnjoj razini.

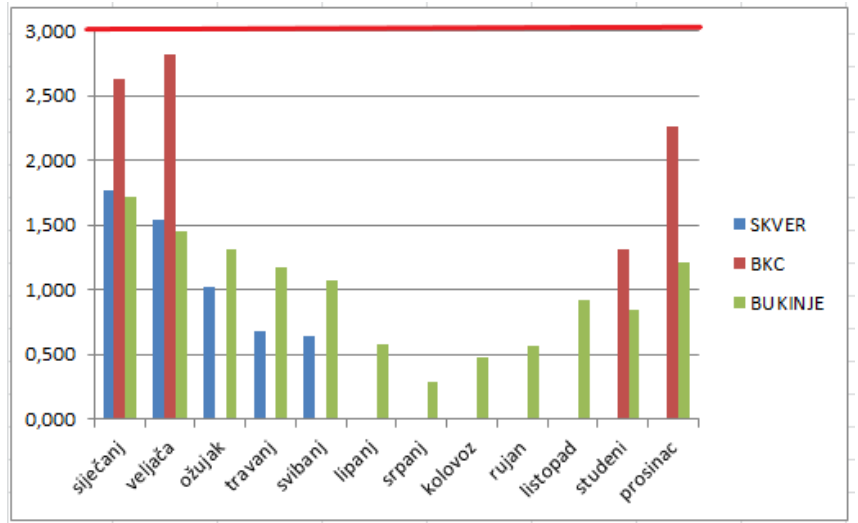

Slika 4 - Prosječne mjesečne vrijednosti za CO

Fig. 4 - Average monthly values for $\mathrm{CO}$

$\mathrm{Na}$ osnovi obrađenih podataka utvrđeno je da koncentracija CO nije prelazila vrijednosti epizoda pripravnosti, upozorenja i uzbune. Izloženost povećanoj koncentraciji vezana je uz pojavu glavobolje, poremećaja vida, smanjene kognitivne sposobnosti, smanjene sposobnosti obavljanje kompleksnih radnji. Vrlo visoke koncentracije mogu dovesti do nesvjestice i smrti. ${ }^{27}$

Na slici 5 prikazana je prosječna mjesečna koncentracija $\mathrm{O}_{3}$. Rezultati monitoringa pokazuju prisutnost ozona, a mjesec s najvećim onečišćenjem je srpanj.

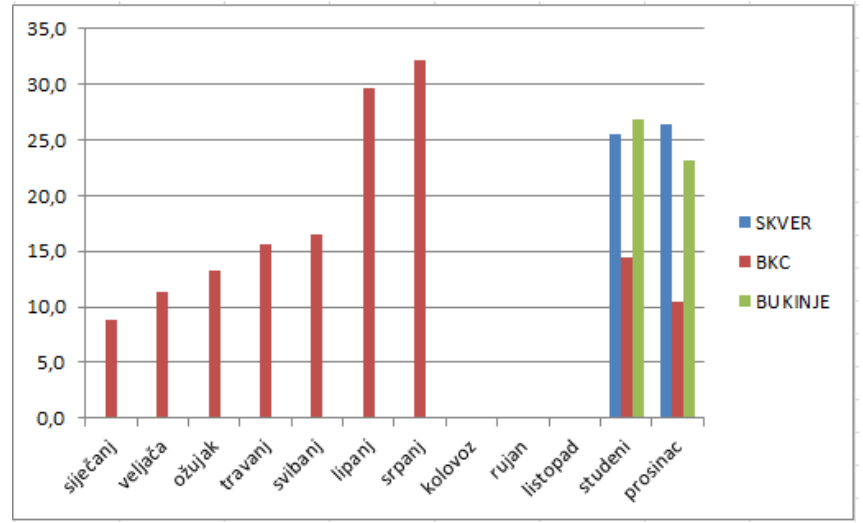

Slika 5 - Prosječne mjesečne vrijednosti za $\mathrm{O}_{3}$

Fig. 5 - Average monthly values for $\mathrm{O}_{3}$

Granične vrijednosti na godišnjoj razini i epizodne vrijednosti nisu propisane Federalnim Pravilnikom. Ozon djeluje nadražujuće na oči i dišni sustav i može izazvati upalu pluća, gubitak daha, bol u prsima, kašalj kao i pojačati već prisutne bolesti dišnih organa poput upale pluća i astme. Dugotrajna izloženost ozonu često je vezana i s kroničnim bolestima dišnih organa. ${ }^{28}$

Na slici 6 prikazana je prosječna mjesečna koncentracija $\mathrm{PM}_{2,5}$. Na osnovi dobivenih podataka s mjernih stanica vidi se velik broj prekoračenja mjesečnih koncentracija $\mathrm{PM}_{2,5}$, a najveće koncentracije zabilježene su u prosincu.

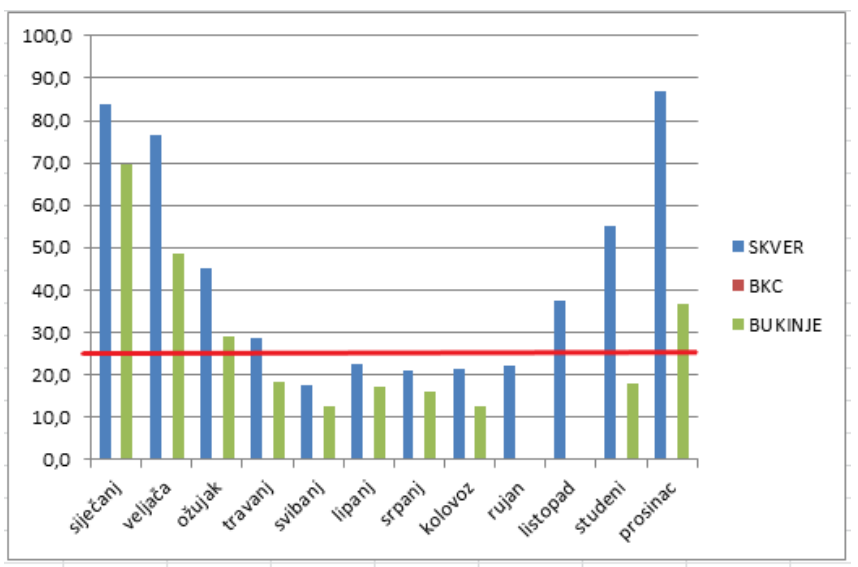

Slika 6 - Prosječne mjesečne vrijednosti za $\mathrm{PM}_{2,5}$

Fig. 6 - Average monthly values for $\mathrm{PM}_{2,5}$

Putem mjernih stanica za praćenje kvalitete zraka utvrđeno je da je došlo do prekoračenja maksimalne dopuštene koncentracije $\mathrm{PM}_{2,5}$ na godišnjoj razini $\mathrm{i}$ to: u siječnju, veljači, ožujku i prosincu na dvije mjerne stanice (Skver i Bukinje) i u travnju, listopadu i studenome na jednoj mjernoj stanici (Skver), a također je utvrđeno da koncentracije tih čestica nisu prelazile epizodne vrijednosti. $\mathrm{PM}_{2,5}$ se obično smatra čak i opasnijim za ljudsko zdravlje zbog svoje male veličine, tako da može prodrijeti duboko u pluća i dalje u krvotok, izazivajući niz zdravstvenih problema uključujući bolesti srca i druge kardiovaskularne komplikacije. ${ }^{29,30}$ 
Povećana koncentracija onečišćujućih tvari na MS1 u zimskim mjesecima može se povezati s pojačanim prometom $\mathrm{i}$ individualnim ložištima. Uzrok povećanja koncentracije onečišćujućih tvari u zimskim mjesecima na MS2 je pretežno željeznički i autobusni promet, ali i individualna ložišta jer se u blizini te mjerne stanice također nalaze stambeni objekti. Povećane koncentracije onečišćujućih tvari na MS3 tijekom zimskih mjeseci povezuju se s radom termoelektrane. Najveći problem onečišćenja u gradu Tuzli predstavljaju $\mathrm{SO}_{2}$ i $\mathrm{PM}_{2,5}$ koji nastaju sagorijevanjem fosilnih goriva, ugljena i nafte $u$ raznim industrijama, termoelektrani, individualnim ložištima i motorima vozila.

$\mathrm{Na}$ osnovi štetnih učinaka za ljudsko zdravlje gore navedenih onečišćujućih tvari oboljenja se mogu podijeliti u dvije skupine: oboljenja respiratornog sustava i oboljenja kardiovaskularnog sustava. $\mathrm{Na}$ oboljenja respiratornog sustava štetan učinak imaju sve obrađene onečišćujuće tvari, dok na oboljenja kardiovaskularnog sustava štetan učinak imaju lebdeće čestice (PM). Podatci o broju oboljelih od respiratornih i kardiovaskularnih bolesti koji su obrađeni preuzeti su sa stranice Zavoda za javno zdravstvo FBiH i Zavoda za javno zdravstvo Tuzlanskog kantona. ${ }^{31}$

U Tuzlanskom kantonu od oboljenja respiratornog sustava u 2019. godini oboljelo je 128982 osobe, a u tablici 3 prikazana su oboljenja respiratornog sustava po starosnim skupinama. Iz te tablice može se zaključiti da štetan učinak prekomjernog onečišćenja zraka najviše utječe na respiratorni sustav djece uzrasta do 6 godina.

Tablica 3 - Broj registriranih oboljenja respiratornog sustava po starosnim skupinama u 2019. godini

Table 3 - Number of registered diseases of the respiratory system by age groups in 2019

\begin{tabular}{l|l|l|l|l}
\hline Dob & $0-6$ & $7-19$ & $20-64$ & $>65$ \\
\hline Broj oboljelih & 49919 & 27249 & 40965 & 10849 \\
\hline
\end{tabular}

Od oboljenja kardiovaskularnog sustava u Tuzlanskom kantonu u 2019. godini oboljelo je 94151 osoba, što se izravno može povezati s veoma štetnim utjecajem lebdećih čestica.

Tablica 4 prikazuje broj oboljelih od kardiovaskularnih bolesti u 2019. godini na području Tuzlanskog kantona, te se može primijetiti da je najviše oboljelih od kardiovaskularnih bolesti u starosnoj skupini od 20 do 64 godine stoga što je ta skupina najviše izložena štetnom učinku onečišćujućih tvari u zraku. ${ }^{32}$

Broj oboljenja od respiratornih i kardiovaskularnih bolesti povećava se iz godine u godinu, a porast je naročito značajan dok traje sezona grijanja. Tada dolazi do pojave prekomjernih koncentracija štetnih tvari u zraku, što negativno utječe na zdravlje ljudi. ${ }^{33,34}$

Tablica 4 - Broj registriranih kardiovaskularnih bolesnika po starosnim skupinama u 2019. godini

Table 4 - Number of registered cardiovascular patients by age groups in 2019

\begin{tabular}{l|c|c|c|l}
\hline Dob & $0-6$ & $7-19$ & $20-64$ & $>65$ \\
\hline Broj oboljelih & 29 & 418 & 54764 & 38940 \\
\hline
\end{tabular}

\section{Zaključak}

Prema podatcima dobivenim iz tri mjerne stanice postavljene u gradu Tuzli, koncentracije onečišćujućih tvari prelazile su granične vrijednosti, pa čak i pragove upozorenja i uzbune i to posebno u zimskom razdoblju. Najveći problem onečišćenja u gradu Tuzli predstavljaju onečišćujuće tvari koje nastaju sagorijevanjem fosilnih goriva, ugljena i nafte $u$ raznim industrijama, termoelektrani, individualnim ložištima i auspusima motornih vozila.

Prekoračenja dopuštenih granica koncentracija onečišćujućih tvari u zraku predstavljaju velik rizik za zdravlje stanovništva i okoliš. Štetni učinci uzrokovani onečišćenjem zraka na ljudskom organizmu jesu toksični, antigeni i karcinogeni učinak.

S ciljem zaštite zdravlja stanovništva, biljnog i životinjskog svijeta, voda i zemljišta, kulturnih i materijalnih vrijednosti te postizanja stalnog poboljšanja kvalitete zraka potrebno je uspostaviti sustav upravljanja kvalitetom zraka u Tuzlanskom kantonu i razraditi mjere zaštite zraka od onečišćenja. Važno je spaljivanje ugljena za zagrijavanje u kotlovnicama i individualnim ložištima svesti na minimum, a daljinsko grijanje proširiti na što veći broj potrošača. Također, s ciljem smanjenja onečišćenja iz motornih vozila, nužno je povećanje kapaciteta javnog prijevoza i podizanje svijesti građana o važnosti korištenja javnog prijevoza.

\section{Popis kratica i simbola List of abbreviations and symbols}

$$
\begin{aligned}
\mathrm{PM} & \text { - lebdeće čestice } \\
& \text { - particulate matter } \\
\mathrm{PM}_{2,5} & \text { - lebdeće čestice promjera manjeg od } 2,5 \mu \mathrm{m} \\
& \text { - particulate matter with less than } 2,5 \mu \mathrm{m} \text { diameter } \\
\mathrm{PM}_{10} & \text { - lebdeće čestice promjera manjeg od } 10 \mu \mathrm{m} \\
& \text { - particulate matter with less than } 10 \mu \mathrm{m} \text { diameter }
\end{aligned}
$$




\section{Literatura}

\section{References}

1. M. Holland, N. Pranjić, Report of air quality in Tuzla Canton from 2009 to 2012 Government of the Tuzla Canton, 2012.

2. N. Pranjić, H. Begić, Lead poisoning of children in Bosnia and Herzegovina (Trovanje djece olovom u Bosni i Hercegovini), Med. Arh. 53/3 (2) (1998) 59-61.

3. H. Begić, F. H. Tahirović, S. Dinarević, V. Ferković, N. Pranjić, Učešće riziko-faktora u nastanku urođenih anomalija srca u djece na području Tuzlanskog kantona Medicinski Arhiv. 56 (2) (2002) 73-77.

4. American Lung Association, Health Effects of Air Pollution, American Lung Association, New York, 1978.

5. M. N. Rao, H. V. N. Rao, Air Pollution, Tata McGraw-Hill, 2007.

6. Baltic University Programme, How Pollution Affects Life, in Environmental Science, 2013.

7. D. A. Vallero, Fundamentals of Air Pollution, $5^{\text {th }}$ Ed., Elsevier Academic Press, Waltham, Mass., 1999, str. 2014.

8. UNEP, Air Pollution and Air Quality. Global Environmental Outlook 3, UNEP, London, Chapt. 2, 2012.

9. D. Kovačić, Zrak i okoliš, Završni rad, Karlovac, 2015.

10. UNICEF: Clear the Air for Children, 2016.

11. M. P. Choudhary, V. Garg, Causes, Consequences and Control of Air Pollution, 2013.

12. D. Hadžić, N. Mladina, F. Ljuca, M. Bazardžanović, Air pollution and Hospital Admission Trends of Children with Bronchial Obstruction in Tuzla Canton. Med Arh. 63 (3) (2009) 146-150.

13. ATSDR, Environmental Medicine; Environmental Health Education (2011-07-01), "Toxicity of Polycyclic Aromatic Hydrocarbons (PAHs): Health Effects Associated With PAH Exposure". Retrieved 2016-02-01.

14. R. Prinn, J. Reilly, M. Sarofim, C. Wang, B. Felzer, Effects of Air Pollution Control on Climate, Human - Induced Climate Change: An Interdisciplinary Assessment, Snowmass Workshop 10th Anniversary Volume, in M. Schlesinger (Ed.), Cambridge University Press., 2005., str. 1-14.

15. M. Krzyzanowski, B. Kuna-Dibbert, J. Schneider, Health Effects of Transport - Related Air Pollution, World Health Organization, Copenhagen, 2005.

16. NASA, Ozone Facts: History of the Ozone Hole, National Aeronautics and Space Administration, 2013.

17. WHO, Air Quality and Health, 2011.

18. S. Patai, The Chemistry of the carbon-nitrogen double bond, John Wiley \& Sons, Ltd., London, 1970. doi: https://doi.org/10.1002/9780470771204.
19. N. Pranjić, Oboljevanje i umiranje ljudi izloženih teškim metalima u neposrednoj blizini odlagališta šljake i pepela Termoelektrane Tuzla 2018.

20. Zakon o zaštiti zraka ("Službene novine FBiH", broj: 33/03 i 4/10).

21. Pravilnik o načinu vršenja monitoringa kvaliteta zraka i definiranju vrsta zagađujućih materija, graničnih vrijednosti i drugih standarda kvaliteta zraka ("Službene novine $\mathrm{FBiH}^{\text {", }}$ broj: $1 / 12$ )

22. URL: http://www.vladatk.kim.ba (6. 5. 2020.).

23. V. Selimbašić, A. Đozić, Osnove ekologije i zaštite okoline, Tuzla 2012.

24. R. Musemić, S. Šahman-Salihbegović, N. Ahmetović, Simulation of pollutant transport and assessment of impacts on human health. J. Trend. Develop. Machin. Assoc. Technol. 16 (1) (2012) 159-162.

25. WHO, WHO Air Quality Guidelines for particulate matter, ozone, nitrogen, dioxide and sulphur dioxide, Global update, 2005.

26. WHO, Health Aspect of Air Pollution with Particulate Matter, Ozone and Nitrogen Dioxide, 2003.

27. NOAA, Trends in Atmospheric Carbon Dioxide, U.S. Department of Commerce, National Oceanic and Atmospheric Administration, 2013.

28. WHO-Europe reports: Health Aspects of Air Pollution, 2003.

29. C. A. Garcia, P.-S. Yap, H.-Y. Park, B. L. Weller, Association of long-term PM2.5 exposure with mortality using different air pollution exposure models: impacts in rural and urban California, Int. J. Environ. Res. Public Healt. 26 (2) (2016) 145-57, doi: https://doi.org/10.1080/09603123.2015.1061113.

30. X. Deng, W. Rui, F. Zhang, W. Ding, $\mathrm{PM}_{2.5}$ induces $\mathrm{Nrf}_{2^{-}}$ mediated defense mechanisms against oxidative stress by activating PIK3/AKT signaling pathway in human lung alveolar epithelial A549 cells, Cell Biol. Toxicol. 29 (2013) 143-157, doi: https://doi.org/10.1007/s10565-013-9242-5.

31. The Lancet, Household Air Pollution Puts More than 1 in 3 People at Risk of III Health and Early Death, ScienceDaily, 2014.

32. J. S. Apte, J. D. Marshall, A. J. Cohen, M. Brauer, Addressing Global Mortality from Ambient $\mathrm{PM}_{2.5}$, Environ. Sci. Technol. 49 (13) (2015) 8057-8066, doi: https://doi.org/10.1021/acs.est.5b01236.

33. K. Simon, G. Hollander, A. McMichael, Evolution of the Immune System in Humans from Infancy to Old Age, Proceed. Royal Soc. B 282 (1821) (2015), doi: https://doi.org/10.1098/rspb.2014.3085.

34. D. A. Vallero, Environmental Contaminants: Assessment and Control, Elsevier Academic Press, Amsterdam/Boston, MA, XXXIX, 2004., p. 801. 


\title{
SUMMARY
}

\section{Monitoring of Pollutants Emissions in the City of Tuzla}

\author{
Emir Hodžić, $a^{*}$ Elma Alić, and Emir Horozića
}

Air pollution is increasingly considered a significant risk to human health. Due to industrial activity, individual fireboxes, and the high traffic concentration, the problem of air pollution has long been present in the Tuzla area. Environmental pollutants cause serious harm to humans and all living things, and pollution from fossil fuel combustion is at the forefront of the black scale of health threats. Environmental pollution can cause a number of diseases such as asthma, allergies, various cancers, heart and circulatory system diseases, fertility problems, neurological problems.

This paper presents the results of monitoring pollutant emissions in the period from Jan 1 to Dec 31, 2019, and the harmful effects of polluted air on the human body. Monitoring at three locations in Tuzla was carried out for the following air pollutants: sulphur dioxide $\left(\mathrm{SO}_{2}\right)$, nitrogen dioxide $\left(\mathrm{NO}_{2}\right)$, carbon monoxide $(\mathrm{CO})$, ozone $\left(\mathrm{O}_{3}\right)$ and $\mathrm{PM}_{2.5}$.

The results showed that, during the heating season (winter months), the air in the urban area of Tuzla was heavily polluted; the highest concentration of sulphur dioxide was recorded in December at the measuring station Bukinje, which amounted to $271.7 \mathrm{~g} \mathrm{~m}^{-3}$. In the same month, the measuring station Skver recorded a concentration of particulate matter $\mathrm{PM}_{2.5} \mathrm{Of}^{153.2} \mu_{\mathrm{g} \mathrm{m}}{ }^{-3}$.

\section{Keywords}

Air pollution, environment, pollutants, monitoring, health

a Faculty of Technology, University of Tuzla,

Conference paper

Urfeta Vejzagića 8, 75000 Tuzla, B\&H

Received April 21, 2020

${ }^{\mathrm{b}}$ Faculty of Medicine, University of Tuzla, Accepted August 17, 2020

Univerzitetska 1, 75000 Tuzla, B\&H 